УАК 351:349.6

ББК $67.401 .14+67.407$

DOI 10.22394/1682-2358-2017-6-11-16

L.N. Borisova, Candidate of Sciences (Law), Docent of the Administrative and Criminal Law Department, Povolzbsky Institute of Management named after P.A. Stolypin, Branch of the Russian Presidential Academy of National Economy and Public Administration; Head of the Saratov OFAS of Russia

\section{ANTIMONOPOLY CONTROL IN THE ECOLOGICAL RELATIONS LEGAL REGULATION MECHANISM \\ (Case Study of the Saratov OFAS of Russia Activities)}

Three aspects of antimonopoly control provided by the ecological relations regulation are considered. Activities of the Office of the Federal Antimonopoly Service in the Saratov Region for antimonopoly control of the ecological relations in the region are analyzed.

Key words and word-combinations: ecological safety, antimonopoly control, aquatic protection activities, preferences, competition.
А.Н. Борисова, кандидат юридических наук, дочент кафедрьг административного и уголовного права Поволжского института управления имени П.А. Стольтина - филиала Российской академии народного хозяйстьа и государственной служби при Президенте РФ, руководитель Сараmовского УФАС России (email: to64@fas.gov.ru)

\section{АНТИМОНОПОАЬНЫЙ КОНТРО $А$ Ь В МЕХАНИЗМЕ ПРАВОВОГО РЕГУ ИИРОВАНИЯ ЭКО ОГИЧЕСКИХ ОТНОШЕНИЙ (на примере деятельности Саратовского УФАС России)}

Аннотация. Рассматриваются три аспекта антимонопольного контроля, предусмотренного регулированием экологических отношений. Анализируется деятельность Управления Федеральной антимонопольной службы по Саратовской области в части антимонопольного контроля экологических отношений в регионе.

Ключевые слова и словосочетания: экологическая безопасность, антимонопольный контроль, водоохранные мероприятия, преференции, конкурс.

B современном мире эффективность мюбой государственной Аеятельности, как правицо, связана с проводимой антимонопольной политикой. Успешность правового регулирования экомогических отношений также зависит от того, в какой мере в Аанном регулировании учитываются антимонопольные требования и стандарты. Используя практический опыт, попытаемся 
проанализировать применение антимонопольного законодательства при осуществлении природоохранных мероприятий. Если вцияние антимонопольного регулирования на общее состояние государственного управления анацизируется во многих публикациях [1-3], то зависимость экологической политики от антимонопоцьной деятельности рассматривается впервые. Рассмотрим несколько направлений вАияния антимонопольного регулирования на природоохранные мероприятия.

ОАним из важнейших факторов, обеспечивающих эффективность экологической политики, является соблюдение конкуренции при использовании бюАжетных средств. Аанную проблему Аля природоохранных мероприятий ярко имлюстрирует следующий пример Саратовского УФАС России.

В июле 2016 г. Саратовское УФАС России рассмотрело информацию Саратовской межкрайонной природоохранной прокуратуры, а также жкалобы ООО «Институт Гипроводхоз» и провело проверки по соблюдению ФеАерального закона от 5 апреля 2013 г. № 44-Ф3 «О контрактной системе в сфере закупок товаров, работ, услуг Амя обеспечения государственных и муниципальных нужкА" (Аалее - Закон о контрактной системе) министерством природных ресурсов и экологии Саратовской области при проведении открытых конкурсов дия субъектов малого предпринимательства, сощиально ориентированных некоммерческих организаций по определению исполнителя следующих услуг: «Определение границ водоохранных зон и границ прибрежных защитных помос реки Аркадак на территории Саратовской области» и «Определение границ водоохранных зон и границ прибрежных защитных полос реки Баланда на территории Саратовской области».

В ходе проведения проверок Саратовским УФАС России было установлено, что указанные закупки размещались на отбор исполнителя услуг по опредемению местоположения береговой минии; сбору, анацизу и обобщению материалов гиАрологической и картографической изученности побережья реки. При этом конкурсная документация закупок не раскрывала требований к результатам оказанных услуг по гидрологической изученности побережья рек, определению гранищ водоохранных зон и гранищ прибрежных защитных поцос водных объектов. К тому же в документации было указано, что материалы считаются соответствующими условиям контракта после принятия их в госуАарственный кадастр недвижимости.

Саратовское УФАС России пришло к выводу о том, что условие о приемке заказчиком разработанной документации после ее принятия в государственном кадастре недвижимости противоречит ч. 13 ст. 34 и ч. 3 ст. 94 Закона о контрактной системе, поскольку возцоженную действующим законодательством на юридическое миџо (государственный орган) обязанность, а при ее невыполнении - ответственность нельзя передать (переложить) на Аругое юридическое миџо (государственный орган) по гражАанско-правовому Аоговору (Контракту).

По итогам рассмотрения жалоб министерству природных ресурсов и экомогии Саратовской были выданы предписания об аннулировании открытых конкурсов, которые были исполнены в установленный срок. Кроме того, 
Аолжностное Аиџо министерства было привлечено к административной ответственности. Рассмотренный пример отражает последствия непрофессионального подхода сотрудников данного ведомства к организаџии закупок. Его действия не только увеличивают временные затраты по определению исполнителей услуг, но и приводят к неэффективному расходованию бюджетных средств Саратовской области, поскольку предметы рассмотренных закупок явцяются государственной потребностью, в связи с чем финансируются за счет среАств бюджета Саратовской области.

Анализ соответствия использования бюджетных среАств при осушествлении экологических мероприятий требованиям антимонопольного законодательства ведется в русле рассмотрения соответствию требованиям законодательства о контрактной системе. В митературе сложились конкретные методы исследования данной проблемы, изложенные в соответствующей митературе, в данной публикации детализировать не будем [4; 5] .

Еще одна проблема - предоставление незаконных преференщий при проведении природоохранной деятельности - подробно анализируется в существующей ситературе [6; 7] .

Ярким примером в области предоставления преференций в цемях охраны окружаюшей среды служит решение Саратовского УФАС России об отказе в предоставлении государственной преференции $\mathrm{AO}$ «Транснефть - Приволга». Так, в июле 2017 г. Саратовское УФАС России рассмотрено заявление ТУ Росимущества в Саратовской области о даче согласия на предоставление государственной преференции $\mathrm{AO}$ «Транснефть - Приволга» в целях защиты окружающей среды в виде предоставления в аренду сооружения берегоукрепления. В ходе рассмотрения заявления было установлено, что проектом договора о передаче в аренду недвижимого имущества, явмяющегося федеральной собственностью, АО «Транснефть - Приволга» предусмотрено переАать в аренду сооружение - берегоукрепление - сроком на 49 мет. В проекте Аоговора было определено, что объект предоставляется в аренду в цемях базирования маломерных судов, необходимых Аля доставки охранно-спасательного оборудования (боновые заграждения и т.п.) к месту мокацизаџии размива нефтепродуктов дия миквидаџии послеАствий аварий на подводных переходах

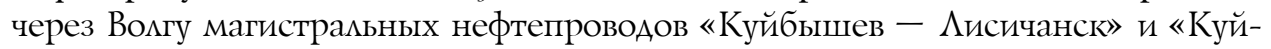
бышев - Тихорецк».

В целях предупреждения и Аиквидации аварийных разливов нефти и нефтепродуктов осушествляется планирование мероприятий в соответствии с постановлением Правительства РФ от 21 августа 2000 г. № 613 «О неотложных мерах по предупреждению и миквидации аварийных разцивов нефти и нефтепродуктов» (вместе с Основными требованиями к разработке планов по предупреждению и ликвидации аварийных разливов нефти и нефтепродуктов), постановлением Правительства РФ от 15 апреля 2002 г. № 240 «О порядке организации мероприятий по преАупреждению и миквидаџии разАивов нефти и нефтепродуктов на территории Российской Федерации», приказом МЧС России от 28 Аекабря 2004 г. № 621 «Об утверждении Правиц разработки и согласования планов по предупреждению и миквидаџии разливов нефти 
и нефтепродуктов на территории Российской Федераџии», приказом МЧС России от 3 марта 2003 г. № 156 «Об утверждении указаний по опредемению нижнего уровня разлива нефти и нефтепродуктов Аля отнесения аварийного разлива к чрезвычайной ситуаџии». Так, приказом МЧС России от 28 декабря 2004 г. № 621 установлено, что в зависимости от уровня возможнной чрезвычайной ситуации организациями разрабатываются планы по предупрежАению и киквидации разливов нефти и нефтепродуктов (Аалее - ПААРН).

Саратовским УФАС России был проведен анализ разработанных и утвержденных Саратовским РНУ филиала АО «Транснефть - Приволга» П ААРНов. Представленные в аАрес Саратовского УФАС России П ААРНы не свидетельствуют о необходимости АО «Транснефть - Приволга» базировать маломерные суда, необходимые Аля доставки охранно-спасательного оборудования (боновые заграждения и т.п.) к месту мокализаџии размива нефтепродуктов Амя миквидаџии последствий аварий на подводных переходах через Волгу магистральных нефтепроводов «Куйбышев - Аисичанск» и «Куйбышев - Тихореџк» с использованием сооружения - берегоукрепления. Указанные документы не предусматривают также нахождение рассматриваемого сооружения-берегоукрепления у АО «Транснефть - Приволга» на праве аренды, собственности, ином вещном праве с цемью базирования судов.

Таким образом, мероприятия по миквидаџии посмедствий размива нефти предусмотрены ПААРНами, в которые не входит базирование маломерных судов, в связи с чем базирование маломерных судов не может быть расценено как защита окружающей среды. Кроме того, установлено, что у АО «Транснефть - Приволга» отсутствуют права на использование акватории водного объекта, в границах которого расположено данное берегоукрепительное сооружение. Таким образом, Саратовское УФАС России пришло к выводу о том, что АО «Транснефть - Приволга» не может быть преАставлена государственная преференщия. Аанный пример показывает значимость проведения антимонопольным органом мероприятий по контролю при предоставлении преференций Амя эффективности экологической политики.

Оптимизация антимонопольного контроля при осуществлении природоохранной деятельности требует совершенствования подзаконного регулирования. По вопросу совершенствования законодательства Саратовское УФАС России считает возможжным внести изменения в постановление Правительства РФ от 14 апремя 2008 г. № 264 «О проведении конкурса на право заключения договора о предоставлении рыбопромыслового участка для осушествления промышленного или прибрежного рыболовства и заключении такого договора», которыми установлены правила организации и проведения конкурса на право заключения Аоговора о предоставлении рыбопромыслового участка Аля осушествления промышиенного ими прибрежнного рыболовства (Аалее - Правила).

Так, по итогам анализа конкурсов на право заключения договора о предоставлении рыбопромыслового участка водоемов Саратовского Завомжья для осушествления промышленного рыболовства на территории области было выявлено, что на этапе вскрытия конвертов с заявками и открытия доступа к заявкам не объявмяются и не заносятся в протокол процедуры вскрытию кон- 
вертов с заявками и открытию доступа к заявкам сведения, на основании которых в Аальнейшем оџениваются и сопоставцяются заявки участников, хотя гц. 6 Правиц порядок рассмотрения заявок четко определен.

Пунктом 28 Правиц установлено, что к заявке прилагаются документы, подтверждающие, во-первых, полномочия миџа на осуществление действий от имени заявителя; во-вторых, наличие у заявителя права собственности или аренды на рыбоперерабатывающий завод; в-третьих, факт внесения заявителем задатка.

Согласно п. 39 Правил при вскрытии конвертов с заявками и открытии доступа к заявкам объявцяются и заносятся в протокол факта вскрытия конвертов с заявками и открытия доступа к заявкам по следующей форме:

- наименование (Аля юридического миџа), Ф.И.О. (Амя ИП) кажАого заявителя, конверт с заявкой которого вскрывается или доступ к поданной в электронной форме заявке которого открывается;

- информаџия о наличии документов, предусмотренных конкурсной Аокументацией;

- предложкение о размере платы, указанное в подпункте «б» п. 27 настоящих Правиц (предложение заявитемя о размере пиаты);

- сведения, содержащиеся в документах, предусмотренных п. 28 настоящих Правиц.

Комиссия проверяет заявителей на соответствие требованиям, установленным п. 12 настоящих Правил (в отношении заявитемя не проводятся проџедуры банкротства и миквидации, деятельность заявителя не приостановлена, отсутствие у заявителя задолженности и др.), а также достоверность сведений, указанных в заявке в соответствии с п. 27 настоящих Правиц.

На основании результатов рассмотрения заявок комиссия принимает решение о допуске или об отказе в допуске заявителей к участию в конкурсе. После этого комиссия осуществляет оценку и сопоставцение заявок и прицагаемых к ним документов. Заявки сопоставцяются и оџениваются в соответствии с критериями на основании информации, преАусмотренной в п. 27 Правил и являющейся неотьемлемой частью заявки. Правила не содержкат требования об объявлении на этапе вскрытия конвертов с заявками и открытия доступа к заявкам предложения участников, которые явцяются критериями отбора.

Отсутствие Аанного требования в Правицах искажкает смысл процедуры проведения конкурса, так как в момент вскрытия конвертов с заявками и открытия доступа к ним предложения участников не оглашаются, а становятся известны значитецьно позже - в момент составления протокола оценки и сопоставления заявок. Необъявление и незанесение в протокол сведений, предусмотренных п. 27 Правиц, на основании которых производится оценка и сопоставление заявок, не способствует принџипам создания дмя заявителей равных условий участия в конкурсе и добросовестной конкуренции, регламентированных в п. 5 Правиц.

В связи с этим Саратовское УФАС России считает необходимым внести изменения в п. 39 Правиц, преАусматривающие обязанность комиссии при вскрытии конвертов с заявками объявцять и вносить в протокоц вскрытия конвертов сведения, предусмотренные п. 27 Правиц. 
Указанный пример имюстрирует актуальность вопроса продовольственной безопасности. Предможенные Саратовским УФАС России изменения будут способствовать развитию конкуренџии среди участников конкурсов на право заключения договора о предоставлении рыбопромыслового участка Аля осуществления промышленного или прибрежного рыболовства, а также становмению процедуры проведения конкурсов более прозрачной.

Таким образом, антимонопольное законодательство играет значительную роль в повышении эффективности экологической деятельности государства. Приведенные примеры имлюстрируют основные направления деятельности антимонопольного органа по обеспечению соответствия природоохранных мероприятий требованиям антимонопольного законодательства.

\section{Библиографический список}

1. Алешин Д.А., Князева И.В., Сушкевич А.Г. Экономический анализ в практике зарубежного антимонопольного регулирования. Новосибирск, 2016.

2. Липатов Э.Г. Отличие норм антимонопольного законодательства от иных административно-правовых средств установления пределов осуществления гражданских права // Актуальные проблемы юридической науки и практики в сфере защиты конкуренции: сборник научных трудов. Саратов, 2016.

3. Долинская B.B. Координация экономической деятельности и недобросовестная конкуренция // Актуальные проблемы юридической науки и практики в сфере защиты конкуренции. Саратов, 2017.

4. Научно-практический комментарий к Федеральному закону «О контрактной системе в сфере закупок товаров, работ, услуг для обеспечения государственных и муниципальных нужд» / пред. редкол. И.Ю. Артемьев. М., 2015.

5. Липатов Э.Г. Экспертиза исполнения обязанностей должностными лицами заказчика как способ установления объективной стороны правонарушения // Актуальные проблемы юридической науки и практики в сфере защиты конкуренции: сборник научных трудов. Саратов, 2017.

6. Караганчу А., Кэраре В. Теория и практика становления конкурентного законодательства М., 2012.

7. ФАС России. Двадцать дел, признанных лучшими по итогам деятельности антимонопольных органов в 2011-2012 годах: сборник материалов. М., 2013. 